\title{
Discussion on ERP Experiment Teaching
}

\author{
Wei Wang \\ School of Economics and Management \\ Jilin Institute of Chemical Technology \\ Jilin, China \\ 422520986@qq.com
}

\begin{abstract}
Through the ERP sand table simulation, the problem of insufficient practical ability and insufficient teamwork in the experimental teaching was solved. The actual teaching method of competition is the innovation of experimental courses, and the simulation of actual combat enables students to experience the pleasure of learning.
\end{abstract}

Keywords-Teamwork; ERP sand table; simulation; economic management; training against confrontation

How to introduce ERP curriculum into university classroom? How to make student learning is no longer a simple and tacit knowledge of the book? How to mobilize the enthusiasm of students? How to improve the combination of theory and practice? Therefore, on the basis of theoretical teaching, it is necessary to combine the company's own practical experience with the advantages of resources of university experts to explore a new mode of personnel training, to enhance students' ability to start a business and innovate to meet the needs of the development of modern enterprises, which is currently problems to be solved in higher education.

\section{INTRODUCTION}

ERP-Enterprise Resource Planning Enterprise Resource Planning, the concept by the United States Garter Group (Gartner Group) first proposed in the early 1990s, refers to the establishment of information technology, based on the systematic management thinking for the corporate decisionmaking layer and staff management tools to provide decisionmaking tools.

Business Operations Sand Table Simulation is a course developed by KlasMellan of the Royal Institute of Technology in Sweden in 1978. It features an experiential training approach that follows the process of 'Experience - Share - Enhance Apply". At the beginning of the 21st century, UFIDA Software Company took the lead in introducing the experiment of sand table into the ERP experiment in Chinese universities. ERP Sand Table Simulation Countermeasure experiment is to simulate the operation status of the enterprise through the intuitive enterprise sand table, so that the students can understand the whole process of the operation of the enterprise in a series of activities such as analyzing the market, making strategy, organizing production, overall marketing and financial settlement, limited resources, so as to deeply understand the management thought of ERP, comprehend the scientific management rules and enhance the management ability. Logistics management is the best way for enterprises to purchase, store and use materials, and ensure the production safety as the premise and maximize the profit. It is the strategy that enterprises seek the optimal allocation of resources under the background of market economy select.

\section{The Superiority of EXPERIMENTAL TEACHING IN ERP SAND TABle Simulation MatCH}

\section{A. Teaching content innovation}

ERP teaching to promote "teacher guidance, students practice their own."[1]Teaching activities shifted from "teaching" to "learning" as the center. Teachers are transformed from educators and inculcators of knowledge into organizers, mentors and promoters of student learning. Classroom teaching consists of listening mode, teachers become teachers to design situations and organizations for students to guide, monitor and assess students' learning activities, multiple thinking co-exist, so that students can make full use of their briars, hands and mouths. Students learning purely from teachers, from within the class shifted into both teachers and classes, but also from other students and extracurricular. Through their own experiences, students realize that they must establish mechanisms for communication and coordination between departments with different positions and establish an organization oriented toward overall interests. Each of them has its own respective responsibility. Otherwise, the major ships will not be able to withstand the impact of storms.

Taking the ERP module as the teaching goal and student teamwork as the learning method, a practice-oriented ERP teaching system is constructed. The teaching system simulates the competitive environment of the company. The students are in a dynamic and complex management environment to simulate the company's finance, logistics, production and marketing processes. With the team members simulating the business relationship in the market, the students experience the company's development strategy in all aspects. Product development, investment in fixed assets, material requirements and procurement plans, capital revolving plans and other specific company operating activities and business processes. By simulating the company's overall operation process for several consecutive years, students fully experience the company's management and decision-making process, grasp the correct way to formulate scientific decisions for the company, understand the important factors of the company's successful operation, promptly enhance innovation capability, and make decisions and operations practical ability.[2] 


\section{B. Teaching means innovations}

ERP sand table simulation training course fully embodies the essence of experiential innovation teaching method. Students have plenty of freedom to experiment with major business decisions and have the direct view of the results. In the fierce competition in the market, they often do not have the opportunity to "say it first". In the experiment we fully provide such an opportunity for students to fully test their decisionmaking ability. Making mistakes in the simulation will not bring any harm to enterprises and individuals. The essence of "learning from mistakes"is fully demonstrated here.

Through the simulation experiment to improve students' practical ability. ERP experiment teaching simulates all the company's activities from establishment to product sales, including a series of activities in company management such as registration, organizational structure, talent recruitment, company operation, product manufacturing, market research, marketing and property management. Experimental teaching is generally provided by teachers from different professional backgrounds to provide professional guidance to students, effectively raising the utilization rate of ERP teaching resources. In addition, the ERP simulation experiment is not limited by time and place, and can be used by the students online for holidays, weekends and other time to improve the simulation experiment efficiency, and to some extent solve the problems such as the lack of internship in the student company, knowledge and skills in entrepreneurial reserve management.

To achieve experimental teaching technology and teaching methods innovation. It is necessary to introduce advanced information technology into the platform construction so as to realize the sharing of experimental teaching network, virtualization and experimental teaching resources. Set up to meet the experimental teaching to carry out student autonomy, cooperative, inquiry, interactive learning software and hardware environment.[3]

\section{Teaching methods innovation}

When choosing teaching methods, it emphasizes the combination of traditional means and modern means, the combination of simulation means and practical means, so as to form a perfect teaching system with combination of emotionally-based teaching, interactive teaching, self-study and role training.

Students learn not simply from teachers, from classes, but also from other students and extracurricular activities. Students through their own relatives, in different positions between the establishment of communication and coordination mechanism, the establishment of overall interest-oriented organizations, each responsible for their own role.[4]

ERP sand table simulation teaching to cultivate students' innovative ability and entrepreneurial ability is obvious for all to see, while obtaining good teaching results; we still need to do a good job in several aspects to ensure the smooth running of teaching, as follows: Open teaching mode. In the simulation process, the surface of the ERP sand table should be entirely dependent on the independent operation of the students. The completed data report can be balanced by the students according to the experimental conditions. All of these need to be adequately prepared before class. The purpose of the experiment is not the final result of the data, but whether the students can accomplish certain tasks according to the specified scenarios and experimental backgrounds during the whole teaching process, so as to realize the impartiality and rationality of ERP sand table operation. Strengthen laboratory construction. By simulating the experimental training of the mode of operation of the enterprise, it can shorten the period of field practice and also overcome the shortage of experimental space and the severe requirements during the teaching period.[5]

The students participate in the decision-making of team management, strategic planning, market research, production planning, market development, R \& D investment, sales management, report analysis, etc. in the enterprise operation management by participating in the operation and management of the virtual enterprise in the simulated business environment. The operation will encounter a variety of decision-making situations, and effective analysis and evaluation, so that all kinds of knowledge and skills in business management have a more profound experience and feelings, effectively transfer what they have learned into practical ability, comprehensive improve overall ability. So as to make up for the lack of traditional teaching mode and improve the status of experimental teaching, laying a good foundation for future employment.[6]

\section{The leap of perceptual and rational understanding}

Perspective ERP sand table simulation competition, it is implied perceptual knowledge and rational understanding of mutual penetration and from rational to leap of practice. ERP sand table competition is the competition in the enterprise market after the game rules are concentrated in so-called "sand table” disk real shots. When a living enterprise with a certain asset is put into the hands of students, students without any entrepreneurial experience are put on a market full of thorns, and they begin to feel the cruelty of competition and the hardships of starting a business.

ERP course teaching requires students to understand both business management knowledge and business process ERP application processing business, students' learning ability put forward higher requirements.[7]

\section{E. Help students develop individual ability}

The introduction of case teaching into the ERP experimental teaching process of undergraduate management can better achieve the organic combination of theory and practice so that students can more intuitively understand the theoretical knowledge of ERP and be familiar with the real business processes and operations Procedures. For management students lacking practical experience in the enterprise, the experiment teaching mode combined with the enterprise case can help them to bring in roles and scene experiences through situational simulation and deepen their understanding of relevant theoretical knowledge On the other hand, the business simulation based on the actual operation of the enterprise can rapidly improve the ability of its business operation and decision-making and judgment, and help enhance the competitive ability of graduating students when they graduate from the job market.[8] 
In the simulated confrontation within our school, a variety of student personality traits are manifested. Some groups have done well in full swing, quite the "stormed Chu Kyushu" posture; some adhering to the "golden mean" work steady and steady; while others are quiet, critical moment surprising victory. Each student in each group also has their own personality traits, conservative, radical, and more adventurous, and these individual differences are most vividly demonstrated during the sand table simulation.

\section{EXPERIMENTAL TEACHING SURVEY RESULTS}

By ERP sand table simulation experiment class, the students have a certain degree of improvement in teamwork awareness, business management, market analysis capabilities, and independent entrepreneurship and so on. The findings are as follows:

TABLE I. STATISTICS T ABLE

\begin{tabular}{|c|c|c|c|}
\hline Investigation project & Great & General & No \\
\hline $\begin{array}{l}\text { 1, After ERP sand table } \\
\text { experiment team awareness of } \\
\text { how to improve }\end{array}$ & $99 \%$ & $1 \%$ & \\
\hline $\begin{array}{l}\text { 2, After the ERP sand table } \\
\text { experiment on how to improve } \\
\text { their understanding of the role }\end{array}$ & $79.38 \%$ & $20.62 \%$ & \\
\hline $\begin{array}{l}\text { 3, After the ERP sand table } \\
\text { experiment on the factory } \\
\text { production have what kind of } \\
\text { understanding }\end{array}$ & $69.07 \%$ & $30.93 \%$ & \\
\hline $\begin{array}{l}\text { 4, After ERP sand table } \\
\text { experiment on business } \\
\text { management what kind of } \\
\text { understanding }\end{array}$ & $74.23 \%$ & $24.74 \%$ & $1.03 \%$ \\
\hline $\begin{array}{l}\text { 5, After ERP sand table } \\
\text { experiment on the market analysis } \\
\text { of how to improve }\end{array}$ & $69.79 \%$ & $29.17 \%$ & $1.04 \%$ \\
\hline $\begin{array}{l}\text { 6, After ERP sand table } \\
\text { experiment factory production } \\
\text { capacity planning and scheduling } \\
\text { of what is the importance of } \\
\text { understanding }\end{array}$ & $73.96 \%$ & $26.04 \%$ & \\
\hline $\begin{array}{l}\text { 7, After ERP sand table } \\
\text { experiment on the material needs } \\
\text { of the plan have what kind of } \\
\text { understanding }\end{array}$ & $78.35 \%$ & $21.65 \%$ & \\
\hline $\begin{array}{l}\text { 8, After ERP sand table } \\
\text { experiments on the limited } \\
\text { resources have any understanding }\end{array}$ & $76.29 \%$ & $21.65 \%$ & $2.06 \%$ \\
\hline $\begin{array}{l}\text { 9, After the ERP sand table } \\
\text { experiment on employment what } \\
\text { kind of help }\end{array}$ & $70.10 \%$ & $21.65 \%$ & $3.09 \%$ \\
\hline $\begin{array}{l}\text { 10, After ERP sand table } \\
\text { experiments on how to improve } \\
\text { their own independent business } \\
\text { confidence }\end{array}$ & $72.16 \%$ & $26.80 \%$ & $1.03 \%$ \\
\hline
\end{tabular}

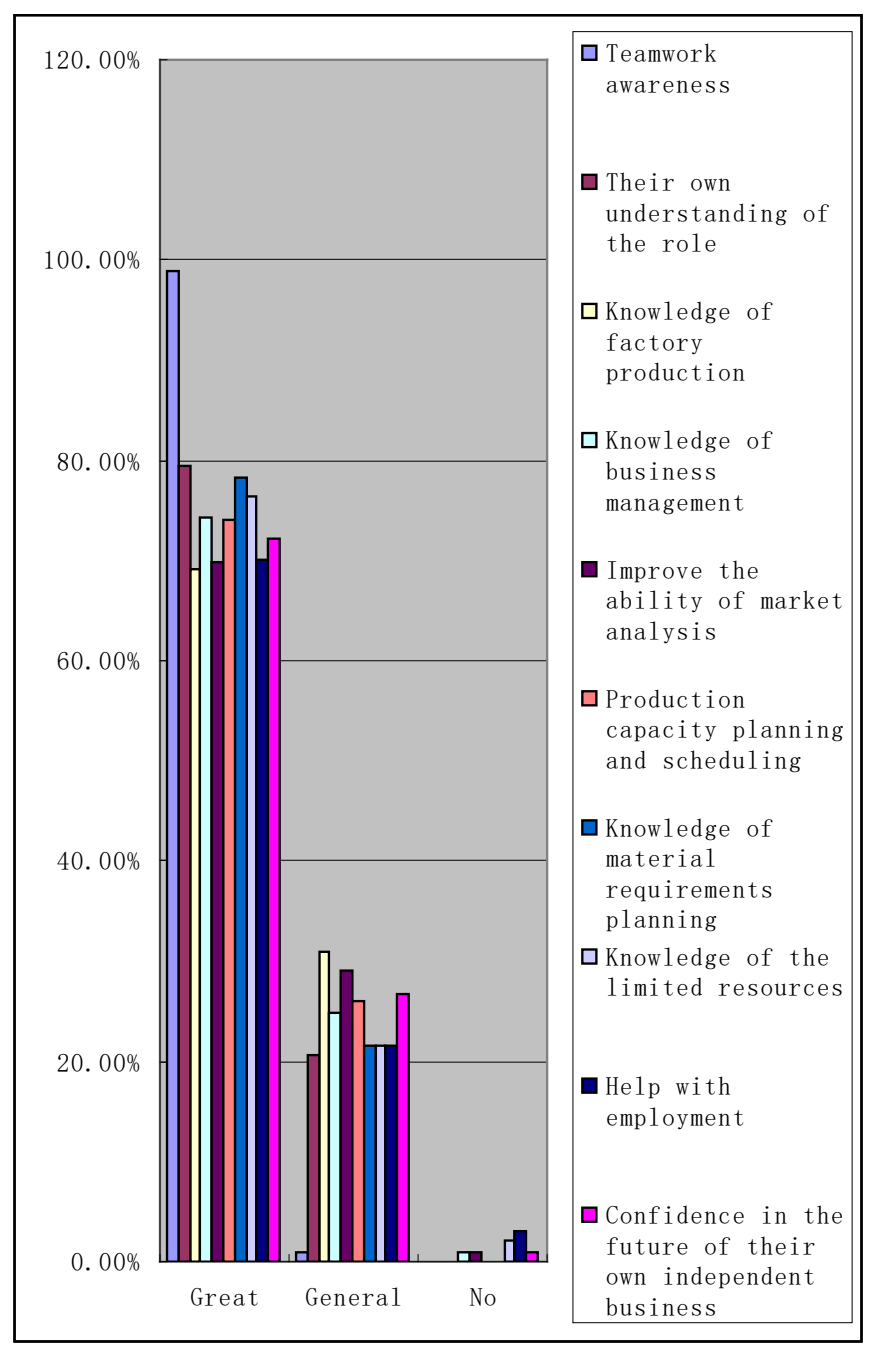

Fig. 1. Statistic chart

Through the histogram, we can clearly see that nearly $70 \%$ of all the survey items have been improved and the students have greatly improved the actual operation of the factory. This complements the end-of-field internship and there is a sense of team cooperation $90 \%$ increase, indicating that through the ERP sand table experiment, the study and practice of students have been greatly improved, the experimental effect is better.

\section{CONCLUSION}

ERP is a highly applied course, through experiments in order to achieve the combination of theory and practice teaching purposes.[9]In order to meet the needs of the development of the market economy, senior economic management personnel should not only have solid knowledge of economic management, but also have good management qualities and strong analytical and problem solving skills, capable of adapting to fierce market competition. The emergence of ERP sand table simulation competition has greatly improved the entrepreneurship and inno vation ability of college students. It is necessary to introduce the ERP sand table simulation competition into the experimental teaching reform. 


\section{REFERENCES}

[1] YE Yi-xiong and ZHANG Li-xin,.Study on ERP Experiment Teaching Guided by Innovation and Entrepreneurship,China Management Informationization, 2014, 108-109.

[2] Pu Xia, Exploration of ERP Experiment Teaching Based on "Double Creations" in Economic Management of Local Universities and Colleges, Contemporary Education Research and Teaching Practice, 2017, 102104.

[3] Wang Xiaoyan and Ruan Jian and Xiong Wenyuan, Research and Exploration in Financial ERP Experiment Teaching Platform Based on Collaborative Innovation, March 2017, 269-273.

[4] Cao Xuan, Manager of Professional ERP Experiment Teaching, CoOperative Economy \& Science, January 2014, 105-106.

[5] Fan Chao and Ren Liping, Analysis of ERP Experiment Teaching to Cultivate Students' Innovation Ability and Entrepreneurial Ability -
Taking Marketing Major as an Example, China New Telecommunications, December 2015, 54.

[6] LIU Wen, Training Mode of Economic Management Talents Based on ERP Experimental Teaching Platform - A Case Study of Hubei Institute of Economics and Management Monthly, November 2013, 106-108.

[7] Liang Qiao, Several Key Problems Affecting ERP Experiment Teaching and Solutions, Commercial Accounting, March 2014, 125-127.

[8] Kim Ra and Zhang Jing,Application of Case Teaching in Experimental Class for Economic Management - Taking ERP Experimental Course of Petroleum University as an Example, Journal of Graduate Education, December 2014, 52-55.

[9] Chen Gong and Niu Qinzhou, Design and Implementation of ERP Experimental Teaching System in Colleges and Universities, Journal of Guilin University of Technology, February 2012, 140-143. 